\title{
Kesesuaian Risiko Pencemaran Antara Inspeksi Sanitasi dan Pemeriksaan Bakteriologi pada Air Kolam Renang di DKI Jakarta, 2005
}

\author{
Endang Darajat*
}

\begin{abstract}
Abstrak
Di Jakarta, setiap hari diperkirakan 8000 orang melakukan aktifitas berenang yang membutuhkan air bersih dalam jumlah yang besar. Air bersih yang digunakan berasal dari air tanah dan Perusahaan Air Minum DKI Jakarta. Jumlah orang yang berenang sangat mempengaruhi kualitas air kolam renang yang harus terus dipertahankan agar terhindar dari risiko pencemaran. Penelitian ini bertujuan mengetahui kesesuaian hasil pengukuran risiko pencemaran dengan inspeksi sanitasi dan pemeriksaan bakteriologik pada air kolam renang di DKI jakarta tahun 2005 Penelitian yang menggunakan disain studi cross sectional mengamati mengamati 30 kolam renang. Variabel yang didiamati adalah 13 variabel inspeksi sanitasi dengan menggunakan adalah univariat dan bivariat. Hitemukan bahwa 13 (44\%) air kolam renang menunjukkan tingkat risiko pencemaran rendah dan 17 (56\%) air kolam renang menunjukkan tingkat risiko pencemaran tinggi. Sedangkan untuk kualitas bakteriologik diketahui $11(36,7 \%)$ air kolam renang berkualitas baik dan 19 (63,3\%) air kolam renang berkualitas buruk. Kesesuaian yang diperoleh adalah 0,733 yang berarti nilai kesesuaian yang baik. Variabel isi air memiliki tingkat risiko pencemaran paling tinggi. Berdasarkan aspek inspeksi sanitasi didapat 8 aspek prediktif dan 5 aspek non-prediktif. Perlu dilakukan pemeriksaan air kolam renang secara berkala serta penyuluhan dan bimbingan pada pengelola kolam renang dan masyarakat tentang kualitas air kolam renang yang baik terhadap kesehatan.

Kata Kunci : Kesesuaian, risiko pencemaran, Inspeksi Sanitasi, Kualitas Bakteriologik, Air Kolam Renang, DKI Jakarta.
\end{abstract}

\begin{abstract}
It was estimated in Jakarta, more then 8000 people swim everyday, so it requires height volume of clean water that comes from ground water as well as DKI Jakarta Municipal Water Corporation. The quality of the swimming pool water will affect the people health. By conducting surveillance, we are able to know the quality of the water and recommending intervention when needed. The objective of this research is to obtain information about compatibility pollution risk level between measurement results of sanitary inspection and bacteriological assessment of the swimming pool water in Jakarta 2005. The research used a sectional cross design with total sample of 30 swimming pools. Variable used in this research are 13 sanitation inspection variables and analized using bivariate method of analyses. About 17 (56\%) of swimming pool water shows the hight risk level of pollolutan. The study also shown that the quality of bacteriology is bed, $(19 ; 63,3 \%)$ is in bad quality. The total compatibility of the swimming fool water is in a good value 73 . Based on sanitation inspection aspect, there are 8 predictive aspects and 5 non predictive aspects. It is important to inspect the swimming pools water periodically, to explain and to guide the swimming pools organizers as well as the society about the importance of swimming pools water quality for health.
\end{abstract}

Keywords: Compatibility, Pollution risk level, Sanitary Inspection, Bacteriological assessment, Swimming pool water, DKI Jakarta. 
Di kota besar seperti Jakarta, air selain dimanfaatkan untuk mandi dan mencuci juga dimanfaatkan untuk keperluan berenang sebagai sarana untuk olahraga dan rekreasi bagi sebagian besar masyarakat. Berenang seolah menjadi satu kebutuhan bagi masyarakat Jakarta. Hal ini dapat dilihat dari keberadaannya baik di lingkungan perumahan, perhotelan maupun di gelanggang renang. Berdasarkan data Dinas Pariwisata DKI Jakarta tahun 2004 terdapat 59 kolam renang di perhotelan, 105 kolam renang di perumahan dan 35 kolam renang digelanggang renang. Berdasarkan data suku dinas olahraga DKI Jakarta tahun 2004,1 diperkirakan hampir 8000 orang setiap harinya melakukan aktifitas renang yang terdiri dari $70 \%$ pelajar dan 30\% masyarakat umum. Air bersih merupakan sumber utama untuk kelangsungan kegiatan kolam renang ini. Sumber air bersih yang digunakan berasal dari Air Tanah 20\% dan Air PAM $80 \% .^{2}$

Air bersih merupakan syarat dari keberadaan kolam renang oleh karenanya air kolam renang tersebut harus memenuhi unsur-unsur yang disyaratkan berdasarkan kesehatan. Ada 3 unsur persyaratan dari air kolam renang, ketiga unsur tersebut adalah unsur fisika, unsur kimia dan unsur mikrobiologi. ${ }^{3}$ Kecepatan pertukaran jasad renik pathogen antara orang-orang dikolam renang menyebabkan sanitasi kolam renang mengalami perubahan. ${ }^{4} \mathrm{Hal}$ ini dapat menyebabkan perubahan unsur mikrobiologi dengan ditandai adanya perubahan jumlah coliform dan kuman. ${ }^{4}$ Dari hal diatas, aspek bakteriologi seringkali menjadi prioritas pada upaya perbaikan kualitas air. Kualitas bakteriologi air kolam renang sangat dipengaruhi oleh beberapa hal seperti jumlah air bersih yang tidak mencukupi, sarana kolam renang yang tidak memenuhi persyaratan, tingkat pengetahuan dan perilaku. Karena hal tersebut, perlu perhatian untuk peningkatkan kualitas bakteriologi air kolam renang melalui surveilans kualitas air yang dilaksanakan melalui kegiatan inspeksi sanitasi (IS).

Untuk mengetahui tingkat risiko pencemaran sarana air kolam renang, Departemen Kesehatan Republik Indonesia pada tahun 1999 khususnya yang menangani penyehatan air melakukan inspeksi sanitasi terhadap sarana air kolam renang dengan mempergunakan formulir inspeksi sanitasi yang sudah baku. Variabel yang terdapat pada formulir inspeksi sanitasi dalam penilaian pemeriksaan kesehatan kolam renang, yaitu persyaratan kesehatan lingkungan dan bangunan, persyaratan kesehatan kamar mandi, persyaratan kesehatan fasilitas sanitasi, pengelolaan sampah, karyawan, kualitas air kolam renang. Pada penelitian ini semua variabel tersebut dapat secara langsung dinilai di lapangan, akan tetapi variabel kualitas air kolam renang harus dilakukan pemeriksaan terlebih dahulu di laboratorium. Permasalahannya adalah apakah tingkat risiko hasil IS telah sesuai dengan kualitas bakteriologik (menurut coliform total dan jumlah kuman). Kenyataan dilapangan menunjukkan tidak semua sarana dengan tingkat risiko pencemaran rendah mempunyai kualitas air kolam renang yang baik. Penelitian ini dilakukan untuk mengkaji kesesuaian antara hasil IS dan hasil pemeriksaan bakteriologik khusus pada air kolam renang.

\section{Metode}

Rancangan penelitian yang digunakan dalam penelitian ini adalah cross sectional. Studi ini dilakukan dengan membandingkan hasil pengamatan tingkat risiko pencemaran dengan menggunakan formulir Inspeksi Sanitasi dan pemeriksaan kualitas bakteriologik di laboratorium. Lokasi penelitian dilakukan di DKI Jakarta dengan waktu penelitian bulan Mei sampai Agustus 2005. Populasi dalam penelitian ini berjumlah 35 kolam renang yang ada di DKI Jakarta. Dengan cara acak didapatkan sampel berjumlah 30 kolam renang umum yang digunakan oleh pelajar dan masyarakat.

Pengumpulan data dilakukan oleh 2 orang petugas laboratorium Kesehatan Daerah Propinsi DKI Jakarta yang dibantu oleh 60 orang mahasiswa Fakultas Ilmu Keolahragaan Universitas Negeri Jakarta yang sebelumnya telah diberikan pelatihan oleh petugas laboratorium. Teknik pengambilan sampel air dilakukan pada pertengahan titik kolam renang yang diambil secara serentak pada waktu yang bersamaan yaitu pada tanggal 3 Juli 2005 jam 10.00 WIB dimana kondisi kolam pada saat itu dalam keadaan ramai. Sampel air kolam renang yang diambil sebanyak 1 liter yang ditempatkan pada botol steril. Selanjutnya sampel air dibawa langsung ke laboratorium departemen kesehatan di jalan percetakan negara jakarta pusat. Setelah data terkumpul maka dilakukan pengolahan data dengan memasukkan data mentah dari kuisioner ke dalam kelompok variabel inspeksi sanitasi dari tiap kolam renang. Kemudian data yang sudah dikelompokkan diberi nilai baik apabila sesuai dengan penilaian yang terdapat dalam kuisioner inspeksi sanitasi dan diberi nilai buruk apabila tidak sesuai dengan kuesioner inspeksi sanitasi.

Data yang telah dikumpulkan kemudian diolah secara statistik melalui beberapa tahapan. Tahapan tersebut meliputi editing, coding, entri data dan pembersihan data. Selanjutnya data diolah dan dianalisis dengan program komputer. Analisa data yang digunakan adalah analisa univariat dan bivariat. Selanjutnya untuk melihat kemaknaan secara statistik dengan menggunakan uji pearson chi-square. Univariat untuk menyajikan data deskriptif dari variabel terikat maupun variabel bebas secara terpisah. Data bivariat untuk menyajikan data mengenai hubungan antara variabel bebas (lokasi, lingkungan, lantai, pencahayaan, kamar mandi, jamban, peturasan, penyediaan air, pembangunan air limbah, pancuran bilas, 
tempat sampah, TPS sementara, area kolam, volume air kolam, bak cuci kaki) terhadap variabel terikat (kualitas air kolam renang).

\section{Hasil}

Hasil pengukuran tingkat risiko pencemaran dengan inspeksi sanitasi menunjukkan bahwa variabel isi air kolam adalah variabel yang paling banyak mengandung risiko, sedangkan variabel yang paling sedikit mengandung risiko adalah variabel dinding. Pada Tabel 1 air kolam renang dikatagorikan kedalam 4 tingkat risiko pencemaran yaitu rendah, sedang, tinggi dan sangat tinggi. Hasil observasi dengan instrumen inspeksi sanitasi ditemukan air kolam renang dengan tingkat risiko pencemaran rendah (R) sebesar 13 (44\%), sedangkan untuk tingkat risiko sedang (S) sebesar $11(36 \%)$, tinggi (T) 4 $(13 \%)$ air kolam renang dan sangat tinggi (ST) sebesar $2(7 \%)$ air kolam renang. Hasil pemeriksaan kualitas bakteriologi air kolam renang dikatagorikan menjadi 4 kualitas yaitu baik, kurang baik, jelek dan sangat jelek.

Tabel 1. Distribusi Air Kolam Renang Menurut Tingkat Risiko Pencemaran dan Kualitas Bakteriologi

\begin{tabular}{lcc}
\hline Variabel & Frekuensi & Persentase \\
\hline Tingkat Risiko Pencemaran & 13 & \\
Rendah (R) & 11 & 44 \\
Sedang (S) & 4 & 36 \\
Tinggi (T) & 2 & 13 \\
Sangat Tinggi (ST) & & 7 \\
Kualitas Bakteriologi & 11 & \\
Baik (B) & 4 & 36,7 \\
Kurang Baik (KB) & 11 & 13,3 \\
Jelek (J) & 4 & 36,7 \\
Sangat Jelek (SJ) & & 13,3 \\
\hline
\end{tabular}

Dari hasil observasi yang dilakukan pada 30 air kolam renang, didapatkan $11(36,7 \%)$ air kolam renang berkualitas baik, kurang baik $4(13,3 \%)$, Jelek 11 $(36,7 \%)$ dan sangat jelek sebanyak $4(13,3 \%)$. Tingkat risiko pencemaran dikatagorikan dalam dua kelompok, yaitu risiko rendah dan risiko tinggi yaitu gabungan dari tingkat risiko pencemaran sedang, tinggi dan sangat tinggi. Berdasarkan Tabel 2 diperoleh hasil bahwa pada tingkat risiko pencemaran rendah, hasil pemeriksaan kualitas bakteriologi sebagian besar baik, yaitu 92,3\%, sedangkan pada kolam renang dengan tingkat risiko pencemaran tinggi, hasil pemeriksaan kualitas bakteriologi sebagian besar adalah buruk, yaitu $82,4 \%$. (Lihat tabel 2).

Untuk hasil uji kesesuaian antara hasil pengukuran tingkat risiko pencemaran dengan inspeksi sanitasi dan hasil pemeriksaan bakteriologi pada air kolam renang, menghasilkan nilai kesesuaian-Kappa sebesar 0,733 artinya terdapat nilai kesesuaian yang baik yang menggambarkan adanya hubungan yang signifikan antara tingkat risiko pencemaran dengan kualitas bakteriologik. Persyaratan kesehatan lingkungan secara umum dilihat dari lokasi dan lingkungan. Berdasarkan Tabel 3 menunjukkan bahwa lokasi dan lingkungan berhubungan dengan kualitas bakteriologi. Pada lokasi yang tidak berisiko ditemukan $83,3 \%$ kualitas bakteriologi baik, dan lokasi yang berisiko ditemukan 100\% kualitas bakteriologi buruk. Pada keadaan lingkungan yang tidak berisiko ditemukan $65 \%$ kualitas bakteriologi baik, dan pada lingkungan yang berisiko ditemukan $80 \%$ kualitas bakteriologi buruk.

Berdasarkan Tabel 4 diperoleh hasil bahwa lantai berhubungan dengan kualitas bakteriologi. Diketahui $62,5 \%$ kolam renang yang lantainya tidak berisiko kualitas bakteriologi adalah baik, dan 100\% lantai yang berisiko, kualitas bakteriologi adalah buruk. Pencahayaan yang berisiko ditemukan $77,8 \%$ kualitas bakteriologi adalah buruk.

Persyaratan kesehatan secara khusus dinilai kamar mandi, jamban dan peturasan. Berdasarkan Tabel 4 diperoleh hasil bahwa kamar mandi, jamban, peturasan tidak berhubungan dengan kualitas bakteriologi. Persyaratan kesehatan fasilitas sanitasi dinilai dari penyediaan air, pembangunan air limbah dan, pancuran bilas. Pembangunan air limbah dan pancuran bilas berhubungan dengan kualitas pemeriksaan bakteriologi air kolam renang.Pengelolaan sampah dinilai dari keadaan tempat sampah, tempat pembuangan sampah sementara, area kolam, volume air kolam, dan bak cuci kaki. Keadaan

Tabel 2. Tabel Silang Risiko Pencemaran dengan Kualitas Bakteriologi

\begin{tabular}{lccccc}
\hline Risiko Pencemaran & \multicolumn{3}{c}{ Kualitas Bakteriologi } & Jumlah \\
\cline { 2 - 4 } & N & $\%$ & Naik & $\%$ & \\
\cline { 2 - 4 } & & & & & \\
Risiko Pencemaran (1) & 12 & 92,3 & 1 & 7,7 & 13 \\
Rendah & 3 & 27,3 & 8 & 72,7 & 11 \\
Sedang & - & - & 4 & 100 & 4 \\
Tinggi & - & - & 2 & 100 & 2 \\
Sangat Tinggi & 12 & 92,3 & 1 & 7,7 & 13 \\
Risiko Pencemaran (2) & 3 & 17,6 & 14 & 82,4 & 17 \\
Rendah & & & & & \\
Tinggi & & &
\end{tabular}


Tabel 3. Hubungan Persyaratan Kesehatan Lingkungan Umum dengan

Kualitas Pemeriksaan Bakteriologi Air Kolam Renang

\begin{tabular}{|c|c|c|c|c|c|c|}
\hline \multirow{3}{*}{ Variabel IS } & \multicolumn{4}{|c|}{ Kualitas Bakteriologi } & \multirow{3}{*}{ Jumlah } & \multirow{3}{*}{ Nilai $p$} \\
\hline & \multicolumn{2}{|c|}{ Baik } & \multicolumn{2}{|c|}{ Buruk } & & \\
\hline & $\mathbf{N}$ & $\%$ & $\mathbf{N}$ & $\%$ & & \\
\hline \multicolumn{7}{|l|}{ Lokasi } \\
\hline Tidak berisiko & 15 & 83,3 & 3 & 16,7 & 18 & 0,000 \\
\hline Berisiko & - & - & 12 & 100,0 & 12 & \\
\hline \multicolumn{7}{|l|}{ Lingkungan } \\
\hline Tidak berisiko & 13 & 65,0 & 7 & 35,0 & 20 & 0,020 \\
\hline Berisiko & 2 & 20,0 & 8 & 80,0 & 10 & \\
\hline
\end{tabular}

Tabel 4. Hubungan Lantai, Pencahayaan, Penyediaan Air, Buangan Limbah, \& Pancuran Bilas, dengan Kualitas Pemeriksaan Bakteriologi

\begin{tabular}{|c|c|c|c|c|c|c|}
\hline \multirow[t]{3}{*}{ Variabel IS } & \multicolumn{4}{|c|}{ Kualitas Bakteriologi } & \multirow[t]{3}{*}{ Jumlah } & \multirow[t]{3}{*}{ Nilai $p$} \\
\hline & \multicolumn{2}{|c|}{ Baik } & \multicolumn{2}{|c|}{ Buruk } & & \\
\hline & $\mathbf{N}$ & $\%$ & $\mathbf{N}$ & $\%$ & & \\
\hline \multicolumn{7}{|l|}{ Lantai } \\
\hline Tidak berisiko & 15 & 62,5 & 9 & 37,5 & 24 & 0,017 \\
\hline Berisiko & - & - & 6 & 100,0 & 6 & \\
\hline \multicolumn{7}{|l|}{ Pencahayann } \\
\hline Tidak berisiko & 13 & 61,9 & 8 & 38,1 & 21 & 0,109 \\
\hline Berisiko & 2 & 22,2 & 7 & 77,8 & 9 & \\
\hline \multicolumn{7}{|c|}{ Kamar Mandi, Jamban, peturasan } \\
\hline Tidak berisiko & 9 & 50,0 & 9 & 50,0 & 18 & 1,000 \\
\hline Berisiko & 6 & 50,0 & 6 & 50,0 & 12 & \\
\hline \multicolumn{7}{|l|}{ Penyediaan air } \\
\hline Tidak berisiko & 10 & 55,6 & 8 & 44,4 & 18 & 0,456 \\
\hline Berisiko & 5 & 41,7 & 7 & 58,3 & 12 & \\
\hline \multicolumn{7}{|l|}{ Pembangunan } \\
\hline Tidak berisiko & 12 & 66,7 & 8 & 33,3 & 18 & 0,025 \\
\hline Berisiko & 3 & 25,0 & 9 & 75,0 & 12 & \\
\hline \multicolumn{7}{|l|}{ Pancuran Bilas } \\
\hline Tidak berisiko & 12 & 66,7 & 6 & 33,3 & 18 & 0,025 \\
\hline Berisiko & 3 & 25,0 & 9 & 75,0 & 12 & \\
\hline
\end{tabular}

tempat sampah, tempat pembuangan sampah sementara, area kolam, dan bak cuci kaki berhubungan dengan kualitas pemeriksaan bakteriologi air kolam renang (Lihat tabel 5).

Aspek inspeksi sanitasi terhadap pemeriksaan bakteriologik air kolam renang merupakan upaya untuk mengetahui sifat prediktif dan non prediktif dari variabel yang diteliti. Diketahui terdapat 8 sifat prediktif dan 5 sifat non prediktif, seperti terlihat pada Tabel 6.

\section{Pembahasan}

Masih banyak faktor - faktor yang berpengaruh pada kualitas bakteriologik air kolam renang yang tidak diamati pada penelitian, seperti pergantian air kolam, tingkat pendidikan, jumlah orang yang berenang, perilaku pengunjung di lokasi penelitian dan waktu penelitian yang dilakukan pada waktu liburan sekolah yang tentunya semua ini akan berpengaruh pada kualitas air kolam renang. Hasil penelitian memperlihatkan kesesuaian hubungan antara variabel inspeksi sanitasi dengan tingkat risiko pencemaran dan kualitas bakteriologik air kolam renang. Berdasarkan observasi 13 variabel inspeksi sanitasi diketahui variabel volume air kolam renang merupakan variabel yang berisiko tinggi. Hal ini disebabkan oleh volume air kolam yang tidak memenuhi persyaratan pemeriksaan inspeksi sanitasi. Temuan 28 (95\%) volume air kolam renang berisiko, menunjukan bahwa air kolam renang di wilayah DKI Jakarta tidak memenuhi persyaratan penilaian pemeriksaan kesehatan kolam renang. Hal tersebut sesuai dengan penelitian sebelumnya bahwa 98,2\% tidak memenuhi persyaratan. ${ }^{5}$ Ditemukan 13 (44\%) air kolam renang berisiko risiko pencemaran rendah dan 17 (56\%) berisiko tinggi. Untuk kualitas bakteriologik, ditemukan $11(36,7 \%)$ air kolam renang berkualitas bakteriologik baik dan 19 (63,3\%) berkualitas buruk. Persentase volume air kolam renang yang tinggi diragukan, karena variabel inspeksi sanitasi untuk volume air kolam renang tidak reliabel. Uji kesesuaian antara tingkat risiko pencemaran dengan kualitas bakteriologik, menunjukkan hasil yg signifikan dengan nilai kesesuaian (Kappa $=0,733$ dan nilai $P=0,000$ ).

Pada risiko pencemaran rendah, hasil pemeriksaan 
Tabel 5. Hubungan Pengelolaan Sampah, TPS Sementara, Area Kolam,

Volume Air dan Bak cuci Kaki dengan Kualitas Bakteriologik

\begin{tabular}{|c|c|c|c|c|c|c|}
\hline \multirow[t]{3}{*}{ Variabel IS } & \multicolumn{4}{|c|}{ Kualitas Bakteriologi } & \multirow[t]{3}{*}{ Jumlah } & \multirow[t]{3}{*}{ Nilai $p$} \\
\hline & \multicolumn{2}{|c|}{ Baik } & \multicolumn{2}{|c|}{ Buruk } & & \\
\hline & $\mathbf{N}$ & $\%$ & $\mathbf{N}$ & $\%$ & & \\
\hline \multicolumn{7}{|l|}{ Tempat Sampah } \\
\hline Tidak berisiko & 14 & 70,0 & 6 & 30,0 & 20 & 0,002 \\
\hline Berisiko & 1 & 10,0 & 9 & 90,0 & 10 & \\
\hline \multicolumn{7}{|l|}{ TPS Sementara } \\
\hline Tidak berisiko & 15 & 75,0 & 5 & 25,0 & 20 & 0,000 \\
\hline Berisiko & 0 & 0 & 10 & 100,0 & 10 & \\
\hline \multicolumn{7}{|l|}{ Area Kolam } \\
\hline Tidak berisiko & 15 & 65,2 & 8 & 34,8 & 23 & 0,006 \\
\hline Berisiko & 0 & 0 & 7 & 100,0 & 7 & \\
\hline \multicolumn{7}{|c|}{ Volume Air Kolam } \\
\hline Tidak berisiko & 2 & 100,0 & 0 & 0 & 2 & 0,483 \\
\hline Berisiko & 13 & 46,4 & 15 & 53,6 & 28 & \\
\hline \multicolumn{7}{|l|}{ Bak Cuci Kaki } \\
\hline Tidak berisiko & 14 & 60,9 & 9 & 39,1 & 15 & 0,080 \\
\hline Berisiko & 1 & 14,3 & 6 & 85,7 & 15 & \\
\hline
\end{tabular}

Tabel 6. Inspeksi Sanitasi Yang Bersifat Prediktif dan Non-Prediktif Terhadap Pemeriksaan Bakteriologik

\begin{tabular}{lcc}
\hline Variabel Inspeksi Sanitasi & P-Value & Sifat Prediksi \\
\hline Lokasi & 0,000 & Prediktif \\
Lingkungan & 0,020 & Prediktif \\
Lantai & 0,017 & Prediktif \\
Pencahayaan & 0,109 & Non Prediktif \\
Kamar Mandi, Jamban, Peturasan & 1,000 & Non Prediktif \\
Penyediaan Air & 0,456 & Non Prediktif \\
Pembangunan & 0,025 & Prediktif \\
Pancuran Bilas & 0,025 & Prediktif \\
Tempat Sampah & 0,002 & Prediktif \\
Tempat Penampungan Sampah Sementara & 0,000 & Prediktif \\
Area Kolam & 0,006 & Prediktif \\
Volume Air Kolam & 0,483 & Non Prediktif \\
Bak Cuci Kaki & 0,080 & Non Prediktif \\
\hline
\end{tabular}

bakteriologik sebagian besar baik yaitu 12 (92,3\%), sedangkan pada tingkat risiko pencemaran tinggi hasil pemeriksaan kualitas bakteriologik sebagain besar buruk yaitu $14(82,4 \%)$. Ini berarti terdapat nilai kesesuaian baik antara tingkat risiko pencemaran dengan kualitas bakteriologik air kolam renang. Penelitian ini sesuai dengan penelitian sebelumnya yang menyatakan kesesuaian antara risiko pencemaran dengan kualitas bakteriologik dengan nilai kesesuai 0,6. Kualitas bakteriologi akan sesuai dengan risiko pencemaran apabila nilai kesesuaian variabel yang diteliti adalah baik. Lokasi sangat berpengaruh terhadap tingkat kesehatan penghuninya.

Lokasi yang baik menurut persyaratan kesehatan tidak terletak pada daerah rawan bencana alam, tidak terletak pada daerah bekas pembuangan sampah dan bekas lokasi pertambangan serta tidak terletak pada daerah rawan kecelakaan dan kebakaran. ${ }^{6,7}$ Kolam renang haruslah mudah diketahui dan juga mudah dijangkau. Hasil penelitian menunjukkan bahwa variabel lokasi secara statistik berhubungan bermakna dengan kualitas bakteriologik air kolam renang (nilai $\mathrm{p}=0,000$ ). Hal ini berarti bahwa lokasi merupakan aspek prediktif dalam inspeksi sanitasi karena nilai p dibawah 0,05 dan menandakan bahwa kolam renang yang berlokasi buruk akan mengalami pencemaran dibandingkan dengan yang berlokasi baik. Tomkins (1992) yang dikutip Linda ${ }^{8}$ menyatakan bahwa lingkungan yang terkontaminasi, sanitasi buruk yang tidak memenuhi syarat kesehatan akan menyebabkan bakteri atau kuman mudah masuk dan menyebabkan infeksi. Lingkungan yang baik harus memberikan rasa aman kepada orang yang berada disekitarnya. Hasil penelitian menunjukkan bahwa variabel lingkungan berhubungan bermakna secara statistik dengan kualitas bakteriologik air kolam renang dimana nilai $\mathrm{p}$ untuk lingkungan 0,020 . Hal ini berarti lingkungan merupakan aspek prediktif dalam inspeksi sanitasi karena nilai $\mathrm{p}$ di bawah 0,05 dan ini menandakan pula bahwa kolam renang yang mempunyai lingkungan buruk akan mengalami pencemaran dibandingkan dengan yang berlingkungan baik.

Hasil penelitian sebelumnya menyebutkan bahwa ada hubungan yang bermakna antara kondisi perumahan dengan kesehatan penghuninya. ${ }^{9}$ Hasil penelitian menunjukkan bahwa variabel lantai berhubungan bermakna secara statistik dengan kualitas bakteriologik air kolam renang, dimana nilai $\mathrm{p}$ untuk lantai 0,017 . Hal ini menunjukkan bahwa air kolam renang yang mempunyai lantai yang buruk akan mengalami pencemaran dibandingkan dengan lantai yang baik. Hal ini berarti bahwa lantai merupakan aspek prediktif dalam inspeksi sanitasi karena nilai $\mathrm{p}$ di bawah 0,05 dan ini menandakan pula bahwa kolam renang yang mempunyai lantai yang buruk akan mengalami pencemaran dibandingkan dengan yang berlantai baik.Pencahayaan dalam ruangan harus 
memenuhi persyaratan kesehatan. Pencahayaan dengan bantuan sinar matahari sangat diperlukan sehingga penataan pencahayaan harus sesuai syarat kesehatan. Cahaya matahari yang masuk minimal \pm 60 lux dan tidak menyilaukan, sehingga cahaya matahari mampu membunuh kuman-kuman patogen dan jika pencahayaannya kurang sempurna akan mengakibatkan ketegangan mata. ${ }^{6}$

Pencahayaan terlihat berhubungan bermakna dengan kualitas bakteriologik. Hal ini menunjukkan bahwa air kolam renang yang mempunyai pencahayaan yang buruk akan mengalami pencemaran dibandingkan dengan lantai yang baik. Hasil tersebut berhubungan dengan kualitas bakteriologik air kolam renang dimana nilai $p=0,109$. Hal ini berarti bahwa pencahayaan merupakan aspek non-prediktif dalam inspeksi sanitasi karena nilai $\mathrm{p}$ di atas 0,05 dan ini menandakan pula bahwa kolam renang yang mempunyai pencahayaan yang buruk akan mengalami pencemaran dibandingkan dengan yang mempunyai pencahayaan baik.

Kamar mandi, jamban dan peturasan merupakan variabel yang paling mudah menimbulkan pencemaran. Ditemukan bahwa kamar mandi, jamban dan peturasan berhubungan bermakna dengan kualitas bakteriologik air kolam renang dimana untuk kamar mandi, jamban, peturasan mempunyai nilai $p=1,000$. Hal ini berarti bahwa air kolam renang yang mempunyai kamar mandi, jamban, peturasan yang buruk akan mengalami pencemaran dibandingkan dengan kamar mandi, jamban, peturasan yang baik. Berdasarkan aspek inspeksi sanitasi diketahui bahwa variabel kamar mandi, jamban dan peturasan termasuk aspek non-prediktif karena nilai p diatas 0,05. Air yang tersedia berasal dari air tanah dan perusahaan air minum.

Penyediaan air dan volume air terlihat berhubungan bermakna dengan kualitas bakteriologik (nilai p untuk penyediaan air 0,456 sedangkan nilai p untuk volume air 0,483). Hal ini menunjukkan bahwa air kolam renang yang mempunyai penyediaan air dan volume air kolam renang yang buruk akan mengalami pencemaran air kolam renang dibandingkan dengan penyediaan air dan volume air kolam yang baik. Dilihat dari aspek inspeksi sanitasi penyediaan air dan volome air kolam renang termasuk aspek non-prediktif karena mempunyai nilai $p$ di atas 0,05. Penyediaan air harus mencukupi untuk kolam renang dan bilas. Volume air kolam renang menurut syarat kesehatan adalah 3 orang $/ \mathrm{m}^{3} .3$ Sirkulasi air harus lancar. Air limbah harus mengalir dengan lancar.

Variabel pembangunan air limbah berhubungan bermakna secara statistik dengan kualitas bakteriologik air kolam renang, dimana nilai $\mathrm{p}$ untuk pembangunan air limbah 0,025. Hal ini menunjukkan bahwa kolam renang yang mempunyai pembangunan air limbah yang buruk akan mengalami pencemaran air kolam renang dibandingkan dengan pembangunan air limbah yang baik.
Hal ini berarti bahwa pembangunan air limbah merupakan aspek prediktif dalam inspeksi sanitasi karena nilai $p$ di bawah 0,05 dan ini menandakan pula bahwa kolam renang yang mempunyai pembangunan air limbah yang buruk akan mengalami pencemaran dibandingkan dengan pembangunan limbah yang baik.

Pancuran bilas harus tersedia, untuk 40 orang minimal tersedia 1 pancuran bilas. Pancuran bilas harus bersih dan tidak bau. Diketahui bahwa hanya variabel volume air kolam yang non-prediktif terhadap kualitas air kolam renang.Tempat sampah sebaiknya terbuat dari bahan yang kuat, ringan, tahan karat dan kedap air, mepunyai tutup yang mudah dibuka dan ditutup. ${ }^{3}$ Sampah yang terdapat diarea kolam renang digolongkan kedalam sampah yang berasal dari tempat umum. TPS yang baik harus memenuhi persyaratan kesehatan seperti tempat tidak permanen, tidak menjadi tempat perindukan serangga atau binatang, mudah dijangkau kendaraan pengangkut. Area kolam renang harus ada pemisah antara orang yang berenang dengan yang tidak berenang. Bak cuci kaki berfungsi untuk membersihkan kaki sebelum masuk kolam. Beberapa kolam renang yang diobservasi banyak yang mengabaikan keberadaan bak cuci kaki. Ukuran minimal bak $1,5 \mathrm{~m} \times 20 \mathrm{~cm}$ dan harus terisi air. ${ }^{10}$

Tempat sampah, TPS sementara, area kolam, bak cuci kaki berhubungan bermakna secara statistik dengan tingkat pencemaran air kolam renang, dimana tempat sampah $(p=0,009)$, TPS sementara $(p=0,001)$, area kolam $(p=0,001)$, bak cuci kaki $(p=0,077)$. Hal ini menunjukkan bahwa air kolam renang yang mempunyai tempat sampah, TPS sementara, area kolam, bak cuci kaki yang buruk akan mengalami pencemaran air kolam renang dibandingkan dengan tempat sampah, TPS sementara, area kolam, bak cuci kaki yang baik. Hasil tersebut berhubungan dengan kualitas bakteriologik air kolam renang dimana untuk tempat sampah $(\mathrm{p}=0,002)$, TPS sementara $(p=0,000)$, area kolam $(p=0,006)$, bak cuci ka$\mathrm{ki}(\mathrm{p}=0,031)$. Nilai $\mathrm{p}$ di atas menunjukkan bahwa variabel bak cuci kaki termasuk aspek non-prediktif sedangkan variabel tempat sampah, TPS, area kolam termasuk aspek prediktif.

\section{Kesimpulan}

Berdasarkan hasil pemeriksaan inspeksi sanitasi, tingkat risiko pencemaran air kolam renang hanya $(57 \%)$. Kualitas bakteriologik berdasarkan coliform ditemukan $50 \%$ air kolam renang dengan kualitas baik. Berdasarkan hasil pemeriksaan jumlah kuman ditemukan 64\% dengan kualitas buruk. Hasil uji kesesuaian Kappa menunjukan adanya kesesuaian antara tingkat risiko pencemaran hasil inspeksi sanitasi dengan kualitas bakteriologik air kolam renang sebesar 0,733. Ditemukan 8 aspek inspeksi sanitasi yang prediktif yaitu lokasi, lingkungan, lantai, pancuran bilas, tempat sam- 
pah, TPS sementara, area kolam dan 5 aspek inspeksi sanitasi non prediktif yaitu pencahayaan, kamar mandi, penyediaan air, volume air, bak cuci kaki terhadap hasil pemeriksaan bakteriologik.

\section{Daftar Pustaka}

1. Dinas Olahraga DKI Jakarta. Sarana olahraga di dki jakarta. Jakarta; 2004.

2. Biro Pusat Statistik. Statistik kesejahteraan rakyat. Jakarta; 2001.

3. Departemen Kesehatan Republik Indonesia. Profil kesehatan indonesia. Jakarta; 1999.

4. E. Jawetz, J.L. Melnick \& E.A. Adelberg. Mikrobiologi untuk profesi Kesehatan. Jakarta; 1986.

5. Mulyana, D. Kesesuaian antara hasil pengukuran tingkat risiko pencemaran dengan inspeksi sanitasi dan hasil pemeriksaan bakteriologi pada air sumur gali di wilayah kerja puskesmas rancabungur kabupaten bogor. [Tesis]. Depok: Fakultas Kesehatan Masyarakat Universitas Indonesia; 2003.

6. Kusnoputranto, Haryoto. Kesehatan lingkungan. Jakarta: Universitas Indonesia; 1985.

7. Susanna, D. Kesehatan lingkungan. Jakarta: Universitas Indonesia; 2001.

8. Linda, Ony. Penerapan analisis survival dalam menentukan faktor yang berhubungan dengan perubahan status gizi anak baduta KEP di kecamatan samalanga, aceh utara tahun 1998 / 1999. [Tesis]. Jakarta: Fakultas Kesehatan Masyarakat Universitas Indonesia; 2000.

9. Kunanto, Gatot. Hubungan karakteristik anak \& keluarga dengan status gizi (KKP) balita di prop. Manulu \& irian jaya. [Tesis]. Jakarta: Fakultas Kesehatan Masyarakat Universitas Indonesia; 1992.

10. Hanif, Sofyan. Profil Atlit DKI Jakarta. Jakarta: FIK-UNJ, 2003. 